\title{
Ancient DNA Studies and African Population History
}

\author{
Mário Vicente and Carina Schlebusch
}

\section{Introduction}

In the last three decades, genetics played an increasingly important role in the inference of human history. Genetic studies provided conclusive information that helped to answer challenging questions, such as the "Out of Africa" migration of modern humans. Moreover, genetics helped to establish Africa as the birthplace of anatomically modern humans. The history of human populations in Africa is complex and includes various demographic events that influenced patterns of genetic variation across the continent. Several studies based on mitochondrial DNA, Y-chromosomes, autosomal markers, whole genomes and ancient DNA, contributed to unraveling the genetic sub-structure of African populations. Through these genetic studies of modern-day, and most recently, ancient African genetic variation, it became evident the deepest population split among modern humans was between southern African Khoe-San populations and other African groups, while the central African rainforest hunter-gatherer groups diverged subsequently from the common human lineage. Furthermore, it was shown that agriculture had a large influence on the distribution of current-day Africans and that West African agriculturist populations populated the whole of sub-Saharan Africa, replacing and/ or assimilating former groups. Other farming groups from Northeast Africa, speaking Nilo-Saharan and Afro-Asiatic languages, admixed with Eurasian groups and also expanded southwards. They settled in East Africa and migrated as far as southern Africa where they admixed with San hunter-gatherer ancestors to form the Khoekhoe herding groups. These later population movements disrupted pre-existing population distributions and complicate inferences regarding deep human history. With the increased availability of full genomic data from diverse modern-day African populations and prehistoric Africans, we will have more power to infer human demography. The first successful ancient DNA studies in Africa and the promise of many more African ancient DNA studies to come, will enable direct temporal comparisons - which will further contribute to unraveling deep human history on the African continent. 
With improvements in laboratory techniques and the strengthening of bioinformatics analysis, we are constantly increasing our ability to analyze ancient DNA more effectively and the next few years will be exciting for investigating human history on the African continent.

The study of human history is a subject where many disciplines converge with a common goal - deciphering the human past. Disciplines such as history, archaeology, paleoanthropology, evolutionary linguistics, and more recently, genetics, analyse different types of data to help unravel human history and the story of our origin. Each field has their own valuable contributions, but they are also subject to their own sets of limitations (Jobling et al., 2014). It is thus important to keep in mind that none of these fields provide an unbiased description of human evolution. Findings from different disciplines should try to complement each other and therefore genetics is often combined with other research fields to help understand the history and evolution of humankind. Rapid developments in the ancient DNA (aDNA) field, extended the power of genetics to make inferences about the history of our species (Nielsen et al., 2017). aDNA offers a unique opportunity to access the genetic variation of past populations and enables us to put past populations in context of present-day genetic variation.

Human population groups from all regions of the world, have unique histories of migration, admixture, and adaptation which have shaped their past. For a long time, human prehistory on the African continent has been actively investigated by the disciplines of archaeology, paleoanthropology and linguistics (Greenberg 1963, Mitchell and Lane 2013, Güldemann 2018, Stringer 2002). Although these fields have greatly contributed to the understanding of our species deep history on the African continent, as well as later population migrations in Africa, key questions regarding African history remain unanswered. Integral to the above, is the question of whether changes in material culture, observed in the archeological record, can be ascribed to 'Pots', or 'People'. In other words, are observed cultural changes a result of the physical migration of people, or alternatively, due to the spread of ideas? Similarly, the spread of a language or change in morphological characteristics are not necessarily always correlated to migration and gene-flow between groups of people. The field of genetics offers a unique possibility to investigate human history with regards to population migration and cultural change. However, complex migration patterns are difficult to disentangle in modern-day genomes and 
ancient DNA studies are ideal to study migration history by directly accessing the genetic variation of pre-historic individuals and comparing this variation to other pre-historic individuals from different temporal and geographic contexts and also to modern-day populations. Furthermore, current-day people who live in certain places may not be representative of the populations who inhabited these areas in the past. With support from aDNA, genetics has started to directly access the genetic variation of human prehistory by comparing it to different temporal and geographic comparative data points, including the populations of today. Perhaps one of the greatest benefits of aDNA will be in understanding how population migration and/or population continuity has impacted the genetic landscape of our species through time. Therefore, while contributions from other disciplines have suggested a complex, multifaceted past, genetic studies on modern populations improved inferences, and now aDNA are helping to clarify even further, the questions surrounding African prehistory.

\section{Ancient DNA in Africa}

Due to the difficulty of extracting DNA from samples from warm climates and the initial focus on European aDNA studies, genome-wide aDNA studies in Africa presently number only few (Table 8.1) (Gallego Llorente et al., 2015, Skoglund et al., 2017, Prendergast et al., 2019, Lipson et al., 2020, Schlebusch et al., 2017, van de Loosdrecht et al., 2018, Fregel et al., 2018, Schuenemann et al., 2017, Rodriguez-Varela et al., 2017). However, with the development of new and improved molecular genetic methods and bioinformatic tools, it is becoming easier to not only extract DNA from samples found in warm climates, but more ancient samples too. At the time of writing this review, only nine studies in total have published ancient genome-wide results from Africa, four studies for North African aDNA and five for sub-Saharan African aDNA (Table 8.1). We analyzed the results of aDNA studies from continental Africa, published to date, in context of modern day African genetic variation (Figure 8.1 and 8.2).

\subsection{North Africa}

In North Africa, human population history has a unique standing, with modern-day groups largely related to Eurasian and Middle Eastern populations, with very low levels of genetic contributions from sub-Saharan Africa (blue dots, Figure 8.1 and heat-map in Figure 8.2C) (Henn et al., 2012, Arauna et al., 2016). A debate existed whether this was the result of Paleolithic back-toAfrica migrations, or migrations connected to the Neolithic period and the 
TABLE 8.1 Summary of genome-wide African ancient DNA studies published to date. Context: LSA Later Stone Age; PN - Pastoral Neolithic; PIA - Pastoral Iron Age; and IA - Iron Age

\begin{tabular}{|c|c|c|c|c|c|c|}
\hline Study & Region & $\begin{array}{l}\text { Current } \\
\text { day African } \\
\text { counties }\end{array}$ & $\begin{array}{l}\text { Date } \\
\text { range } \\
\text { Cal BP / } \\
\text { BP }\end{array}$ & Context* & $\begin{array}{l}\text { N Capture } \\
\text { / Full } \\
\text { genomes }\end{array}$ & Coverage \\
\hline $\begin{array}{l}\text { Schuenemann } \\
\text { et al. } 2017\end{array}$ & $\begin{array}{l}\text { Northeast } \\
\text { Africa }\end{array}$ & Egypt & $\begin{array}{l}2726- \\
195^{2} \\
\text { calBP }\end{array}$ & $\begin{array}{l}\text { Pre- } \\
\text { Ptolemaic } \\
\text { Period, } \\
\text { Ptolemaic } \\
\text { Period }\end{array}$ & 3 Capture & $\begin{array}{l}132,084 \text { to } \\
508,36 \text { o SNPS }\end{array}$ \\
\hline $\begin{array}{l}\text { Rodriguez- } \\
\text { Varela et al. } \\
2017\end{array}$ & $\begin{array}{l}\text { Northwest } \\
\text { Africa }\end{array}$ & $\begin{array}{l}\text { Canary } \\
\text { Islands }\end{array}$ & $\begin{array}{l}951- \\
1421 \\
\text { ВР }\end{array}$ & - & $\begin{array}{l}5 \text { Full } \\
\text { genomes }\end{array}$ & 0.21 to $3.93 x$ \\
\hline $\begin{array}{l}\text { van de } \\
\text { Loosdrecht } \\
\text { et al. } 2018\end{array}$ & $\begin{array}{l}\text { Northwest } \\
\text { Africa }\end{array}$ & Morocco & $\begin{array}{l}15,100- \\
13,900 \\
\text { calBP }\end{array}$ & $\begin{array}{l}\text { LSA/ } \\
\text { Paleolithic }\end{array}$ & 5 Capture & $\begin{array}{l}343,764 \text { to } \\
1,013,869 \text { SNPs }\end{array}$ \\
\hline $\begin{array}{l}\text { Fregel et al. } \\
2018\end{array}$ & $\begin{array}{l}\text { Northwest } \\
\text { Africa }\end{array}$ & Morocco & $\begin{array}{l}7,275^{-} \\
5,600 \\
\text { calBP }\end{array}$ & $\begin{array}{l}\text { Early } \\
\text { Neolithic } \\
\text { Late } \\
\text { Neolithic }\end{array}$ & $\begin{array}{l}13 \text { Full } \\
\text { genomes } \\
\text { and } \\
\text { capture }\end{array}$ & $\begin{array}{l}\text { Full gen: } 0.01 \text { to } \\
\text { O.74x } \\
\text { Capt: } 0.04 \text { to } \\
1.72 \mathrm{X}\end{array}$ \\
\hline $\begin{array}{l}\text { Gallego } \\
\text { Llorente et al. } \\
2015\end{array}$ & East Africa & Ethiopia & $\begin{array}{l}4500 \\
\text { calBP }\end{array}$ & LSA & $\begin{array}{l}\text { 1 Full } \\
\text { genome }\end{array}$ & $12.5^{x}$ \\
\hline $\begin{array}{l}\text { Skoglund et } \\
\text { al. } 2017\end{array}$ & $\begin{array}{l}\text { East and } \\
\text { southern } \\
\text { Africa }\end{array}$ & $\begin{array}{l}\text { South } \\
\text { Africa, } \\
\text { Tanzania, } \\
\text { Malawi }\end{array}$ & $\begin{array}{l}8173^{-} \\
3^{22} \\
\text { calBP }\end{array}$ & $\begin{array}{l}\text { LSA } \\
\text { PN } \\
\text { IA }\end{array}$ & $\begin{array}{l}12 \text { Capture } \\
3 \text { Full } \\
\text { genomes }\end{array}$ & $\begin{array}{l}\text { Full gen: } 0.7 \text { to } \\
2.0 x \\
\text { Capt: } 9,355 \text { to } \\
845 \text {,o16 sNPs }\end{array}$ \\
\hline $\begin{array}{l}\text { Schlebusch } \\
\text { et al. } 2017\end{array}$ & $\begin{array}{l}\text { Southern } \\
\text { Africa }\end{array}$ & $\begin{array}{l}\text { South } \\
\text { Africa }\end{array}$ & $\begin{array}{l}2296- \\
282 \\
\text { calBP }\end{array}$ & $\begin{array}{l}\text { LSA } \\
\text { IA }\end{array}$ & $\begin{array}{l}7 \text { Full } \\
\text { genomes }\end{array}$ & 0.01 to $13.2 \mathrm{x}$ \\
\hline $\begin{array}{l}\text { Prendergast } \\
\text { et al. } 2019\end{array}$ & East Africa & $\begin{array}{l}\text { Kenya, } \\
\text { Tanzania }\end{array}$ & $\begin{array}{l}4080- \\
160 \\
\text { calBP }\end{array}$ & $\begin{array}{l}\text { LSA } \\
\text { PN } \\
\text { PIA } \\
\text { IA }\end{array}$ & 41 Capture & 0.01 to $3.9 \mathrm{x}$ \\
\hline $\begin{array}{l}\text { Lipson et al. } \\
2 \mathrm{O} 2 \mathrm{O}\end{array}$ & $\begin{array}{l}\text { West } \\
\text { Africa }\end{array}$ & Cameroon & $\begin{array}{l}7,920- \\
2,970 \\
\text { вР }\end{array}$ & $\begin{array}{l}\text { Stone to } \\
\text { Metal Age }\end{array}$ & $\begin{array}{l}4 \text { Capture } \\
2 \text { Full } \\
\text { genomes }\end{array}$ & $\begin{array}{l}\text { Capt: } 0.7 \text { to } 7.7 \mathrm{x} \\
\text { Full gen: } 3.9 \text { to } \\
18.5 \mathrm{x}\end{array}$ \\
\hline
\end{tabular}


A

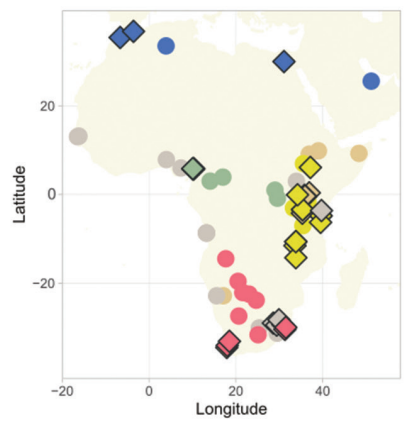

aDNA

East African Hunter-Gatherers

Mota (1)

Kenya 500BP (1)

Kenya LSA (1)

Tanzania Zanzibar 1400BP (1)

Tanzania Pemba 1400BP (1)

Malawi Fingira 2500BP (1)

Malawi Fingira $6000 \mathrm{BP}(1)$
Malawi Hora Holocene (1)

West African Hunter-Gatherers

Shum Laka 3000BP (2)

Shum Laka $8000 B P(2)$

Southern African Late Stone Age

S. Africa LSA (BBay) 2000BP (2)

S. Africa LSA Cape 2000BP (2)

$\mathrm{S}$. Africa LSA Pastoralist 1200BP (1)

Egypt Plol

Morocco IAM EN (1)

Morocco Paleo (4)
B

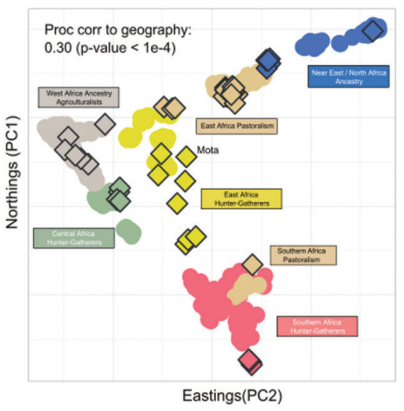

Modern day populations

Southern Africa HG East Africa HG

$\begin{array}{ll}\text { Ju|'hoansi } & \text { Ogiek } \\ \text { !Xuun } & \text { Sabue }\end{array}$

!Xuun

Naro

Xade

Khutse

$\ddagger$ Khomani

Karretjie

Nama (Pastoralists)

Rain Forest HG

Baka

Biaka

Mbuti

Batwa

Sengwer

Sandawe

Hadza

East Africa Pastoral

Amhara

Oromo

Somali

N. Africa / Near East

Mozabite

Qatar

\section{C}
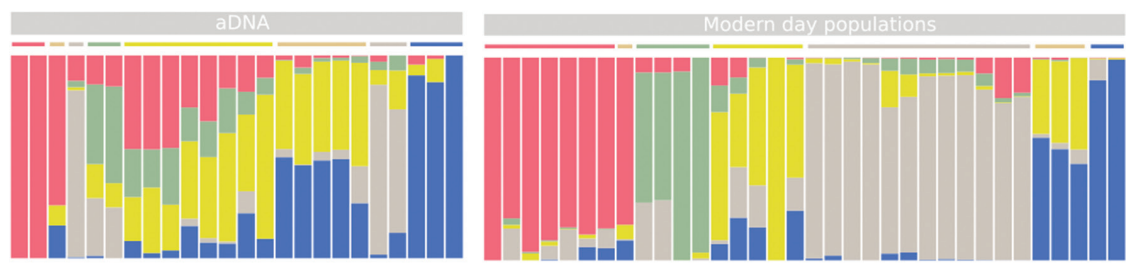

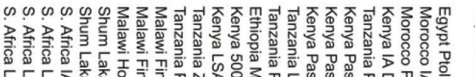
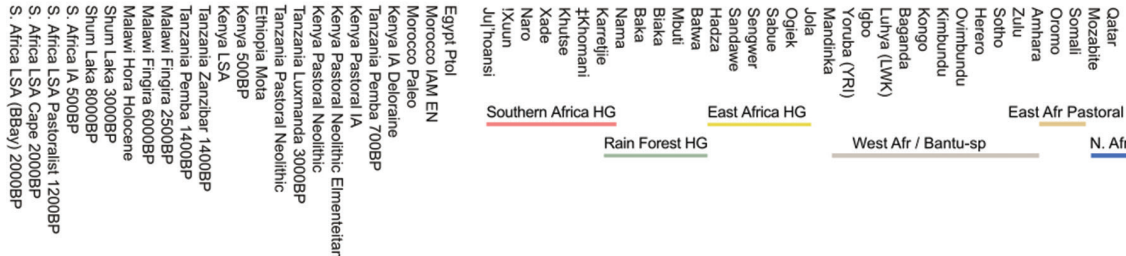

Southern Africa $\mathrm{HG} \quad$ East Africa $\mathrm{HG}$

Rain Forest HG

West Afr / Bantu-sp

East Afr Pastoral

N. Afr

FIGURE 8.1 Modern-day and ancient genetic structure in Africa. A. Geographic locations of modern-day populations (colored circles) and remains of ancient individuals for whom DNA could be extracted and analyzed (diamonds with border). B. PCA rotated to geography PC1 vs. PC2. (rotation to geography were done using Procrustes analysis). C. Averaged per population admixture clustering analysis for $\mathrm{K}=5$. PCA analysis and Admixture were performed on overlapping SNP positions from: Li et al., 2008, Schlebusch et al., 2012, Perry et al., 2014, Auton et al., 2015, Gurdasani et al., 2015, Rodriguez-Flores et al., 2016, Patin et al., 2017, Scheinfeldt et al., 2019, Vicente et al., 2019, Skoglund et al., 2017. Positions with more than 0.15 missingness were discarded, in the end 182,977 LD-pruned SNPS were analyzed. Only aDNA samples with at least 15,00o overlapping SNPs were considered in the analyses 
A

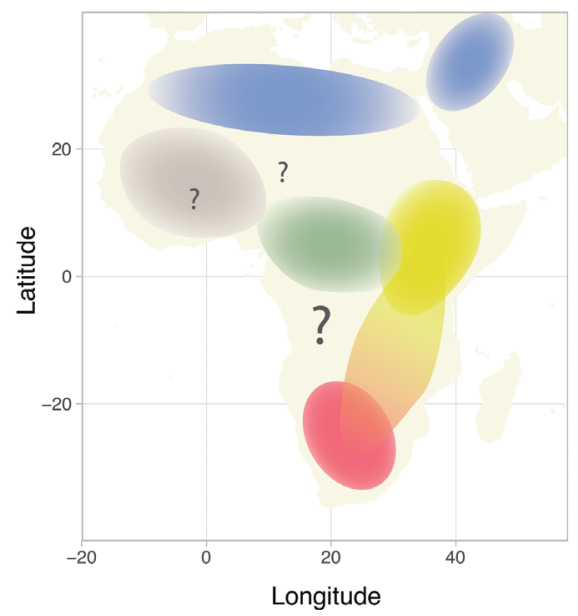

B

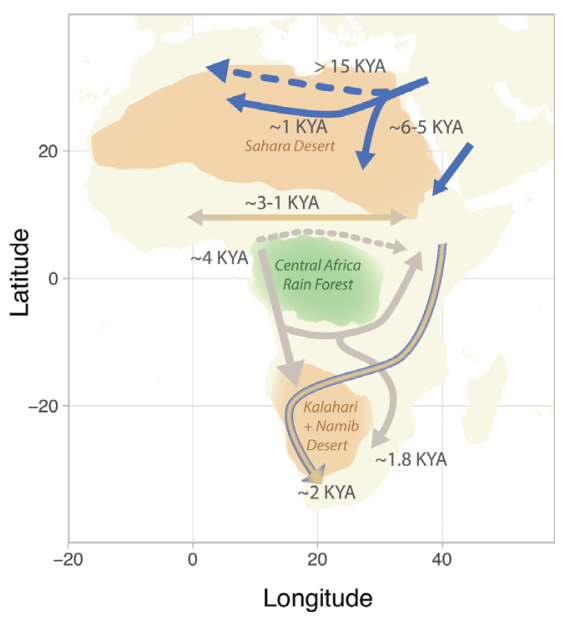

FIGURE 8.2 A. Map of pre-farming population stratification across the African continent, showing non-Africans (blue), East Africans (yellow), West Africans (gray), central African hunter-gatherers (green), and Khoe-San (red). B. Migration routes related to the expansion of herders and crop farmers during Holocene times. The gray arrows represent the Bantu expansion, the blue arrows represent the Eurasian back-migration, the brown/blue arrow represents the southward migration of mixed East African/Eurasian pastoralists, and the gray/brown arrow represents bidirectional migration across the Sahel belt. Abbreviation: KYA, thousand years ago

introduction of farming practices to North Africa (Barbujani et al., 1994, Henn et al., 2012). Ancient DNA studies in early Neolithic ( 7 kya - thousand years ago) Moroccan remains (blue diamonds, Figure 8.1) (Fregel et al., 2018) indeed found the individuals to be genetically most similar to Anatolian farmers and Natufians from the Middle East, suggesting a potential early migration of these groups westward (Fregel et al., 2018). However, a study on 15 kya old remains from Morocco conclusively demonstrated that northern Africa received significant amounts of gene-flow from Eurasia predating the start of the Holocene and the development of farming practices (van de Loosdrecht et al., 2018). aDNA studies further found that the Early Neolithic North Africans ( 7 kya) trace their ancestry to these Paleolithic north African groups (Fregel et al., 2018), while Late Neolithic groups ( $\sim 5 \mathrm{kya}$ ) contains an Iberian component, indicating trans-Gibraltar gene-flow. These two different signals in the Early and Late Neolithic indicate that the spread of farming practices in North Africa involved both the movement of ideas and people [See further information in Chapter 7].

The Sahara isolates North Africa from the rest of Africa and poses a barrier to human migration, aside from intermittent greening periods (Drake et al., 
2011). Gene flow from the south, across the Sahara into modern-day North Africans, seemed to have been low and appeared in relatively recent times (Henn et al., 2012). In the easternmost part of North Africa, ancient DNA studies of mummies also indicated that gene flow from sub-Saharan was recent and that people in classical Egypt displayed less sub-Saharan admixture compared to present-day Egyptians (Schuenemann et al., 2017). More ancient individuals from Morocco however seem to have had higher affinities to sub-Saharan Africans (van de Loosdrecht et al., 2018, Fregel et al., 2018) (Figure 8.1B) and the 15 kya Paleolithic individuals (van de Loosdrecht et al., 2018) derived onethird of their ancestry from sub-Saharan Africans. This sub-Saharan ancestry was best represented by an equal mixture of present-day East African huntergatherers and West Africans (van de Loosdrecht et al., 2018).

The Paleolithic (15 kya) and Early Neolithic (7 kya) individuals lived before and during the most recent green Sahara period (stretching from 12 kya to 5 kya) and yet they have similar genetic compositions with similar affinities to sub-Sahara Africa, while modern-day North Africans have very little subSahara African contribution. Little is known about the peopling of the Sahara during the last humid period, when the desert was replaced by a fertile Savanna grassland. An aDNA study generated two mitochondrial genomes from $\sim 7$ kya individuals associated to a Middle Pastoral (Neolithic) context from the central Sahara region (Vai et al., 2018). These individuals carried a lineage basal to the Eurasian haplogroup N. While the result demonstrated the presence of an ancestral lineage of the $\mathrm{N}$ haplogroup in the Holocene green Sahara it is unclear whether the haplogroup originated in Africa and subsequently was lost due to drift or population replacement, or whether the haplogroup was introduced by a back migration into Africa. Consequently, the cycling of the Sahara through its wet and dry phases seems to have had an influence on the amount of gene-flow between North and Sub-Sahara Africa, although the exact dynamics of those migrations need to be further investigated, ideally through genome-wide ancient DNA studies.

\subsection{Sub-Sahara Africa}

Modern and ancient DNA studies for sub-Saharan Africa indicated that this part of the continent had two very different phases in its history (Figure 8.3) (reviewed in (Schlebusch and Jakobsson 2018)). During the deep history of sub-Saharan Africa, before the invention and spread of farming practices, hunter-gather groups seemed to have been related in an "isolation-by-distance" pattern where geography played an important role. This pattern entails that groups are closest related to their neighboring groups and less related to groups that are geographically further away in a step-wise manner. This isolation-by-distance pattern was shown to drive genetic structure among southern 

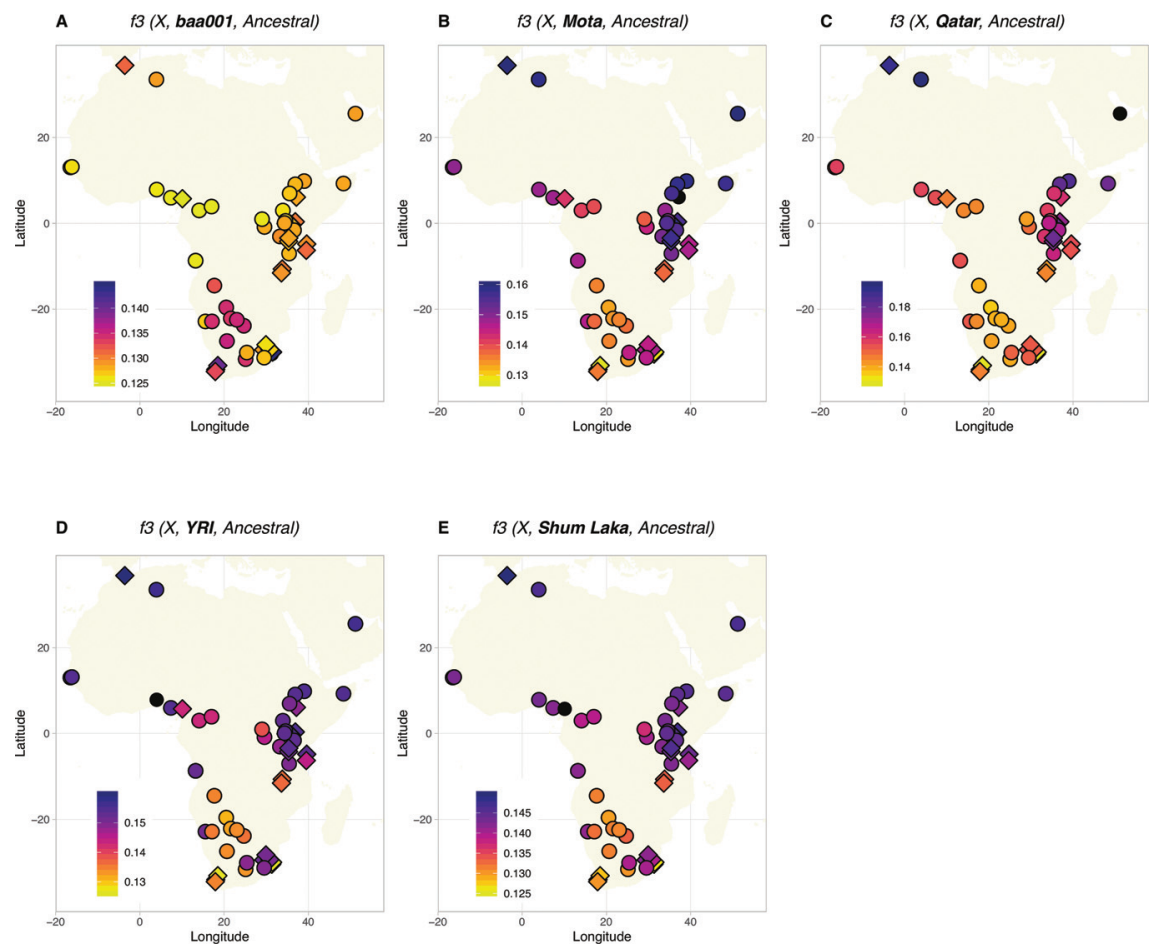

FIGURE 8.3 Genetic affinities among sub-Saharan current-day (coloured dots) and ancient individuals (diamonds with borders) as represented by heat maps of $f_{3}$-outgroup analyses. A. Affinities to "Ballito Bay A" (baaoo1) representing the southern African aboriginal component. B. Affinities to "Mota" representing the East African aboriginal component. C. Affinities to Qatar representing the back migration of non-Africans into Africa. D. Affinities to Yoruba from Nigeria (YRI) representing a West African component and illustrating the Bantu expansion. E. Affinities to Shum Laka representing the Central African aboriginal component. For all $f_{3}$-analyses the Ancestral outgroup was generated from the identified allele present in at least two reference genomes of Chimpanzee, Gorilla and Orangutan. $f_{3}$-outgroup analyses were performed only within samples with at least 10,000 pairwise overlapping SNPS

African hunter-gathers (Vicente et al., 2019) and a simple Procrustes analysis suggest that this pattern also might apply on a continental scale (see procrustes correlation factor in Figure 8.4). Thus the geographic distance across the continent is highly correlated with the genetic relatedness of groups.

The early history of the African continent (captured by genetic relatedness among hunter-gatherer groups) is in stark contrast with the large population movements that followed the invention of farming practices in Africa. The development of food-producing lifeways caused dramatic population increases followed by migrations, which is visible in the genetic signatures 
of expanding farming populations who spread across the whole continent within a relatively short time period (Figure 8.3) (Schlebusch 2019, Schlebusch and Jakobsson 2018). African farming societies outcompeted the autochthonous hunter-gatherer groups who, to a large extent, were replaced and/or assimilated by the farming groups. The origins of food-producing practices in Africa are still unclear but it is believed that crop cultivation was developed independently, in at least three regions in Africa: the Sahara/Sahel (around 7 kya), the Ethiopian highlands ( 7-4 kya), and western Africa ( $\sim 5^{-3}$ kya). The Nile River Valley is thought to have adopted agriculture $(\sim 7-8 \mathrm{kya})$ from the Neolithic transition in the Middle East ( 10-11 kya) (Jobling et al., 2014, Mitchell and Lane 2013). From these centers of origin, farming practices spread to the rest of Africa, with domesticated animals reaching the southern tip of Africa around 2 kya and crop farming around $1.8 \mathrm{kya}$ (Mitchell and Lane 2013). Genomic investigations of both present-day and past humans contributed to hypotheses regarding the spread of farming groups in Africa.

\subsection{Migrations of Food Producers in Sub-Sahara Africa}

The first African ancient DNA nuclear genome to be sequenced was that of a 4.5 thousand year old Ethiopian individual (from Mota, Figure 8.1) (Gallego Llorente et al., 2015). This genome revealed that East African populations, more recent in time than 4.5 kya (beige dots and diamonds, Figure 8.1), have been influenced by a back to Africa migration(s) from a population(s) genetically similar to early Neolithic farmers from Western Eurasia (heat map in Figure 8.2C). On the principal component analysis (PCA) (Figure 8.1) this can be seen through the current day East African populations (beige dots) and ancient East African individuals from farming contexts (beige diamonds) who are intermediate between the Mota individual (yellow diamond - Mota is a representative non-admixed East African hunter-gatherer) and non-Africans (blue dots). This study clearly indicated a Eurasian back migration into East Africa that caused many current-day East African groups to display genetic variation that link them to both groups with a deep East African history (as represented by Mota) as well as Eurasian groups that migrated back into Africa. However, subsequent genetic studies showed that certain Northeast and East African groups, such as the Nilotic speaking Dinka and Nuer groups from Sudan (Hollfelder et al., 2017) and East African hunter gatherers such as the Sabue (Scheinfeldt et al., 2019) (Figure 8.1C and Figure 8.2B and 8.2C), until today had little to no Eurasian admixture.

A study that sequenced 15 ancient Africans across eastern and southern Africa dating as far back as 8.1 kya (Skoglund et al., 2017), also found evidence of this Eurasian back migration into East Africa. The study furthermore found 
that ancient herders carrying this East African-Eurasian mixed ancestry migrated all the way down into southern Africa to introduce herding practices to the south of the continent (beige diamonds and dots in Eastern and Southern Africa, Figure 8.1B). The individual from Kasteelberg in South Africa, found in a pastoralist context (S. Africa LSA Pastoralist 1200 before present (BP) on Figure $8.1 \mathrm{C}$ ) was found to have received $40 \%$ of her ancestry from the pastoralist individual from Luxmanda (Tanzania Luxmanda 3000 в on Figure $8.1 \mathrm{C}$ ) and the rest of her ancestry from southern African hunter-gatherers (South Africa LSA Cape 2000 в ) (Skoglund et al., 2017). This finding confirmed previous results based on modern-day autosomal (Schlebusch et al., 2012, Pickrell et al., 2012, Pickrell et al., 2014), Y-chromosome (Henn et al., 2008) and Lactase Persistence (LP) (Breton et al., 2014, Macholdt et al., 2014) variants, which detected the presence of an East African component in Southern African herders (see the East African component in the southern African herding population "Nama" in Figure 8.1C).

The introduction of farming in East Africa was further refined by a study of 41 individuals associated with Later Stone Age (LSA), Pastoral Neolithic (PN), and Iron Age (IA) contexts in current day Kenya and Tanzania (Prendergast et al., 2019). The study inferred two phases of admixture associated with the spread of pastoralists in the region: the first admixture event likely occurred $\sim 6-5$ kya in northeastern Africa between a group carrying non-African genetic ancestry (related to the groups from the Levant or North Africa) and a local northeast African group (related to present day Dinka/Nuer), and the second admixture event occurred $\sim 4$ kya between this admixed group and eastern African foragers (related to Mota and Kenyan LSA individuals). The route of this non-African component into East Africa is as yet unclear and was proposed to be either through the Nile valley or through the horn of Africa. Results in the study also pointed to at least two chronologically distinct southwards movements of herders into eastern Africa, an initial limited spread and a later more successful spread giving rise to the PN culture. Interestingly genetic analyses failed to find any differentiation between two archeologically distinct PN cultures, Elmenteitan and Savanna Pastoral Neolithic cultures (Figure 8.1C) (Prendergast et al., 2019). The Savanna Pastoral Neolithic was previously hypothesized to be affiliated with Afro-Asiatic speakers and the Elmenteitan with an expansion of pastoralists speaking Nilo-Saharan languages (Ambrose 2001). This observation suggests that cultures that are archeologically very distinct, do not necessarily imply genetically distinct groups. The subsequent arrival of the Iron Age in East Africa was a similarly complex process. An additional Sudan related gene flow event contributed to the Pastoral Iron Age (PIA) in the region (Kenya Pastoral IA in Figure 8.1). This was closely followed by 
the introduction of western African-origin ancestry related to present-day Bantu-speakers into the area that also marks the onset of the Iron Age in the region and the introduction of crop farming (Kenya IA Deloraine and Tanzania Pemba 7Оо в P) (Prendergast et al., 2019, Skoglund et al., 2017).

The Bantu Expansion is one of the largest Holocene expansion events globally and began around $\sim 5^{-3}$ kya in western Africa (in the region of current eastern Nigeria and western Cameroon) (de Filippo et al., 2012, Bostoen 2018, $\mathrm{Li}$, Schlebusch, and Jakobsson 2014). It is visible in the archaeological record via increased sedentism, followed by the spread of agricultural practices and the use of iron (Bostoen 2018, Mitchell and Lane 2013). Today, the majority of sub-Saharan Africans speak one of the $\sim 500$ closely related Bantu languages even though they are distributed over an area of $\sim 500,000 \mathrm{~km}^{2}$. Earlier genetic studies on autosomal data have indicated that the current distribution of Bantu-speaking populations is largely a consequence of the movement of people (demic diffusion) rather than a diffusion of only language (Tishkoff et al., 2009, Li, Schlebusch, and Jakobsson 2014, Schlebusch et al., 2012, de Filippo et al., 2012). This has been confirmed by ancient DNA studies; i.e. ancient remains found in Iron Age contexts (gray diamonds on Figure 8.1), in Eastern Africa (Prendergast et al., 2019, Skoglund et al., 2017) and Southern Africa (Schlebusch et al., 2017) group genetically with current-day West African groups on the PCA (Figure 8.1 A-C). This testifies to the relatively recent, large scale movement of people of West African descent to the rest of the continent, coupled with the spread of agriculture and the use of iron (illustrated by the heat map of Figure 8.2D).

A study that sequenced the nuclear genomes of 7 ancient southern African individuals, three dating to the LSA ( 2 kya - red diamonds in southern Africa - Figure 8.1), and 4 dating to the Iron Age (300 to 400 years ago - gray diamonds in Southern Africa - Figure 8.1) found that the LSA individuals were related to current day Khoe-San hunter-gatherer individuals (red dots) and the Iron Age individuals to current day West Africans (gray dots). This study confirmed a large-scale population replacement in southern Africa, where LSA ancestors of the Khoe-San hunter-gatherers were replaced by incoming Bantu-speaking farmer groups of West African genetic ancestry. In southern Africa, Bantu-speakers received substantial amounts of gene-flow from local Khoe-San hunter-gatherers (e.g. see in S. Africa IA 500 BP ancient individuals and Zulu and Sotho modern day populations, Figure 8.1C). Interestingly, further north, the Bantu-expansion seemed to have had different demographic dynamics in terms of interaction between hunter-gatherers and incoming farmers. Current day populations from Malawi (Skoglund et al., 2017) and Mozambique (Semo et al., 2019) show little to no admixture with hunter-gather 
groups that occupied the area before the Bantu-expansion. These findings indicate that the diffusion of Bantu languages and culture throughout subequatorial Africa was a complex process and the admixture dynamics between farmers and hunter-gatherers played an important role in creating patterns of genetic diversity. Further ancient DNA studies and better coverage of subequatorial Africa in terms of modern-day populations are needed to further clarify the demographic dynamics, migration routes and interactions during the Bantu-expansion.

\subsection{Sub-Sahara Africa before Farming}

Before the large-scale migrations of farming groups across the continent, hunter-gatherer groups seemed to have been related in clinal patterns with geographic distance between groups and the landscape determining relationships. This isolation-by-distance pattern is still reflected in the relatedness between present day hunter-gatherer groups. Southern Africa Khoe-San hunter-gatherers follow an isolation-by-distance pattern of relationship when all admixed parts of their genomes (contributed by West African Bantu-speaking farmers and herders of East African origin) are removed (Vicente et al., 2019). Likewise, the ancient DNA study by Skoglund et al (Skoglund et al., 2017) also found that before farming, a genetic cline between hunter-gatherer populations of East and southern African existed (yellow to red cline on PCA - Figure 8.1). The cline showed a gradient of decrease for a Southern African genetic component towards Eastern Africa (Figures 8.2A and 8.4D) and, similarly, a gradient of decrease in Eastern African ancestry towards southern Africa (Figures 8.2B and $8.4 \mathrm{E}$ ). As a result, LSA Malawi hunter-gatherers had intermediate amounts of genetic contribution from both Eastern and Southern Africa. This cline might also have extended to West Africa and ancient hunter-gatherers from Shum Laka in West-central Africa (current day Cameroon) (Lipson et al., 2020), related to current day West-central African rainforest hunter-gatherers (RHGs) (green dots, Figure 8.1) fall intermediate between southern African hunter-gathers and West African Niger Congo speakers on PC 1 (Figure 8.1B). A PCA that included only ancient and modern-day hunter-gatherers and excluded farming groups (Figure 8.4) show a Procrustes correlation factor with geography of $77 \%$. While, when farmers are included in the analyses, the correlation coefficient is reduced to $30 \%$ (Figure 8.1).

A two-dimensional reduction of the genetic components of hunter-gatherers (e.g. Figure 8.4), might thus suggest long term clinal relationships between groups driven by geographic distance across the African landscape, with few large scale migrations (characteristic of the farming period). This hypothesis however needs to be thoroughly tested with data from more aDNA studies. 
A

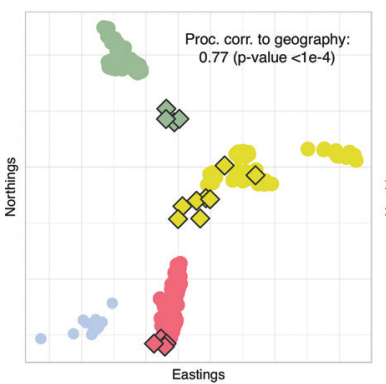

D

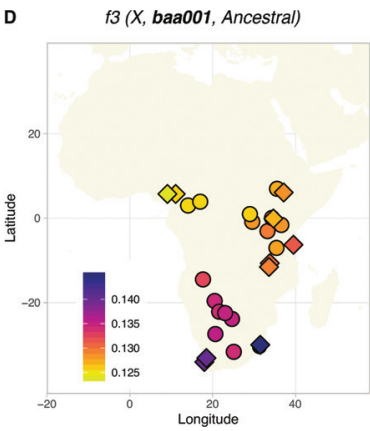

B

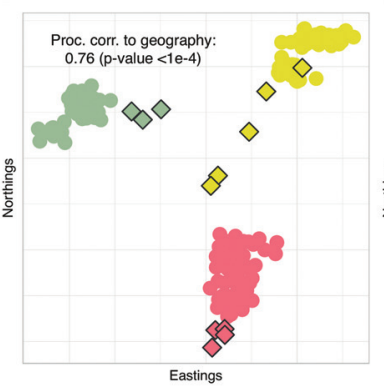

E $c$

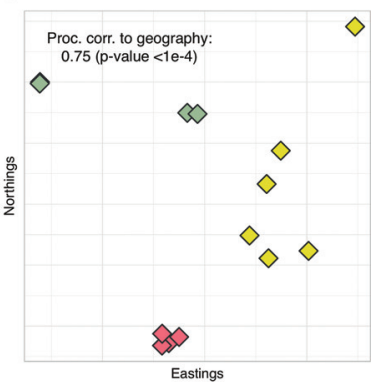

F $\quad f 3(X$, Shum Laka 3000BP, Ancestral)

FIGURE 8.4 Genetic affinities among sub-Saharan current-day (coloured dots) and ancient hunter-gatherers (diamonds with borders), attempting to represent pre-farming population structure. (A) PCA including only sub-Saharan modern-day and ancient hunter-gatherers. Yellow - East African, Green - West/Central African, Pink - Southern Africa. The Qatari population (light blue) was used to extract Eurasian admixture on $\mathrm{PC} 1$ (not shown). $\mathrm{PC} 2$ and 3 were rotated to geography. The Procrustes correlation factor with geography is $77 \%$. (B) Multidimensional scaling (MDS) analysis of pairwise (1 minus $f_{3}$-outgroup) including current-day and ancient hunter-gatherers. The Procrustes correlation factor with geography is $76 \%$. (C) MDS analysis of pairwise (1 minus $f_{3}$-outgroup) including only ancient hunter-gatherers. The Procrustes correlation factor with geography is $75 \%$. The Procrustes correlation factor with geography of A-C is $75-77 \%$, compared to $30 \%$ when farmers are included - Figure 8.1. (D-F) Heat maps of $f_{3}$-outgroup analyses including current-day and ancient hunter-gatherers. D. Affinities to Ballito Bay A (baaoo1) representing the southern African aboriginal component. E. Affinities to Mota and the East African aboriginal component. F. Affinities to Shum Laka representing the Central African aboriginal component. In B-F, the Ancestral outgroup was generated from the identified allele present in at least two reference genomes of Chimpanzee, Gorilla and Orangutan. $f_{3}$-outgroup analyses were performed only within samples with at least 10,000 pairwise overlapping SNPS

From European modern-day (Novembre et al., 2008) and subsequent aDNA studies (Gunther and Jakobsson 2016), we have learnt that isolation-bydistance patterns can also mask several large scale movements and replacements in the distant past, especially if no un-admixed present day groups are 
remaining. In contrast to Europe, Africa still had current-day hunter-gatherer groups left, connected to deep histories in their regions, which simplified and supported inferences based on modern-day genetic variation. Nonetheless, the deep history of Africa remains to be clarified further and aDNA studies already started to contribute to inferences.

In the study by Schlebusch et al (Schlebusch et al., 2017), one of the 2 kya individuals, related to present-day Khoe-San groups, yielded particularly good ancient DNA and was sequenced to $13 \mathrm{x}$ genome coverage. This high coverage ancient genome was used as a reference ancient genome for subsequent analyses. It revealed that all modern Khoe-San groups, have 9-22\% admixture from the admixed group of Eurasian-East African ancestry that introduced herding into southern Africa. This can be seen on the PCA (Figure 8.1B) as a shift in modern day Khoe-San groups (red dots) towards the East African side of the PCA. This result will have an effect on past genomic research as one of the KhoeSan groups, the Ju|'hoansi was considered as a group with very little admixture from neighbouring groups, and was used previously to date the first divergence event between modern human population groups (Schlebusch et al., 2012, Gronau et al., 2011, Veeramah et al., 2011). When the high coverage ancient individual, as a non-admixed San ancestral group, was compared to other Africans to re-estimate the earliest divergence time between modern human groups, a deeper divergence time was obtained (Schlebusch et al., 2017). Whereas past research estimated a divergence time of around 100 thousand years, (200 thousand, using the updated human mutation rate) (Schlebusch et al., 2012, Gronau et al., 2011, Veeramah et al., 2011), using the non-admixed Stone Age individual pushed back the divergence time to between 26o-350 thousand years, towards the genesis of the Middle Stone Age when humans became morphologically and behaviourally modern. Using a coalescent-based tree model, the study found hierarchical divergence times, first between, Khoe-San and all other populations (mean of $322 \mathrm{kya}$ ), followed by the split of RHGs and all other populations (221 kya) followed by a split between West and East Africans (137 kya) (Schlebusch et al., 2017).

While hierarchical bifurcating tree models provide a good estimation of general relatedness between groups, it certainly is a simplified representation of human history and more complex models incorporating gene-flow, migration and deep population structure (sometimes referred to as ghost archaic admixture in the African context) need to be considered in future research (Henn, Steele, and Weaver 2018). Several studies have already reported evidence of deep coalescencing lineages in west Africa suggesting possible deep rooting admixture by a "ghost" population - a population distantly related to modern humans that do not exist as a separate population today (Schlebusch 
et al., 2017, Skoglund et al., 2017, Lachance et al., 2012, Hsieh et al., 2016, Durvasula and Sankararaman 2020). Furthermore, a recent study (Chen et al., 2020) also suggested extensive Neanderthal admixture in African populations, adding additional deep structure to the African demographic picture. These additional deep rooting gene-flow events thus need to be incorporated in models of deep human history in Africa. A study by Lipson et al (Lipson et al., 2020), suggested radiations between four ancestral groups rather than a bifurcating split model. This four-fold radiation involved; a lineage leading to Khoe-San hunter-gatherers, a lineage leading to RH Gs, a lineage leading to East and West Africans and a fourth "ghost modern" lineage of a population that does not exist anymore today. In this model a "ghost-archaic" source was also added and West African groups contained low amounts of ghost-archaic admixture, together with a larger amount of ghost-modern admixture. There were however other models that also fitted their data, for example a model where only one ghost population, with an intermediate divergence time between the ghost-modern and ghost-archaic source, admixed into West Africans.

With more and more evidence from the paleoanthropology and genetics fields, adding support for a possible multiregional origin of modern humans on the African continent (Scerri et al., 2018, Stringer 2016, Schlebusch and Jakobsson 2018, Henn, Steele, and Weaver 2018), future generic studies on deep African history need more rigorous testing. This will require hypothesis testing through the simulation of representative models and thorough testing of these models employing appropriate summary statistics that are sensitive to distinguish between models. Furthermore, geographic and climatic modelling need to be incorporated in these models, together with time-serial data obtained from aDNA studies (Fenderson, Kovach, and Llamas 2020). Although this represents a demanding task, some frameworks have already been laid regarding proposed models (Henn, Steele, and Weaver 2018) and methods to incorporate spatiotemporal components (Fenderson, Kovach, and Llamas 2020). As more data becomes available in the form of aDNA together with genomic data from modern-day African populations, research will continue to clarify the picture of our deep genetic history in Africa and bring us closer to answering the questions of human origins.

\section{Future of Ancient DNA research}

Ancient DNA methods are continually evolving, and we see evidence of this in how research has advanced in the last decade. Improvements in laboratory techniques allowed for sequencing of DNA samples from areas prone to bad 
DNA preservation, such as southern Europe, the Middle East, Southeast Asia and Africa. In areas where DNA preservation is favourable, such as Europe, there are now data from hundreds of ancient individuals to strengthen bioinformatics analysis and increase the amount of reliable information on the ancient populations analyzed. As ancient DNA is becoming more common as means of interpreting human history, researchers are improving bioinformatics pipelines to specifically handle ancient DNA sequence data and population genetic analysis techniques are also tailored to incorporate time-serial data. In the future, ancient DNA research will continue to reveal more nuanced stories of human prehistory, and these stories might help us to understand the present, and better predict how we may react in the future in an ever-changing environment.

\section{Acknowledgements}

The computations were performed at the Swedish National Infrastructure for Computing (SNIC-UPPMAX). C.S. is funded by the European Research Council (ERC - no. 759933). We would like to thank Alexandra Coutinho, Cesar FortesLima, Concetta Burgarella and Imke Lankheet for useful discussions and valuable suggestions. An authorized NIH Data Access Committee (DAC) granted data access to C.S. for the controlled-access genetic data analysed in this study that were previously deposited by Scheinfeldt et al., 2019 in the NIH dbGAP repository (accession code phsoo178o.vı.p1; date of approval: 2019-05-17). For the genomewide genotype data from the (Patin et al., 2017) study (EGA accessory numbers: EGADooo10oo1209), data access was granted via European GenomePhenome Archive (EGA) by the GEH Data Access Committee EGACoooo10oo139.

\section{References}

Ambrose, S. 2001. East African Neolithic. In: Encyclopedia of Prehistory. Springer: New York, USA. pp. 97-109.

Arauna, L.R., Mendoza-Revilla, J., Mas-Sandoval, A., Izaabel, H., Bekada, A., Benhamamouch, S., Fadhlaoui-Zid, K., Zalloua, P., Hellenthal, G., and Comas, D. 2016. Recent Historical Migrations Have Shaped the Gene Pool of Arabs and Berbers in North Africa. Molecular Biology and Evolution 34(2): 318-329.

Barbujani, G., Pilastro, A., De Domenico, S., and Renfrew, C. 1994. Genetic variation in North Africa and Eurasia: neolithic demic diffusion vs. Paleolithic colonisation. American Journal of Physical Anthropology 95(2): 137-154. 
Bostoen, K. 2018. The Bantu Expansion. In: Oxford research encyclopedia of African history. Oxford University Press: Oxford, UK.

Breton, G., Schlebusch, C.M., Lombard, M., Sjodin, P., Soodyall, H., and Jakobsson, M. 2014. Lactase persistence alleles reveal partial East african ancestry of southern african Khoe pastoralists. Current Biology 24(8): 852-858.

Chen, L., Wolf, A.B., Fu, W., Li, L., and Akey, J.M. 202O. Identifying and Interpreting Apparent Neanderthal Ancestry in African Individuals. Cell 18o(4): 677-687 e616. doi: 10.1016/j.cell.2020.01.012.

de Filippo, C., Bostoen, K., Stoneking, M., and Pakendorf, B. 2012. Bringing together linguistic and genetic evidence to test the Bantu expansion. Proceedings of the Royal Society B: Biological Sciences 279(1741): 3256-3263.

Drake, N.A., Blench, R.M., Armitage, S.J., Bristow, C.S., and White, K.H. 2011. Ancient watercourses and biogeography of the Sahara explain the peopling of the desert. Proceedings of the National Academy of Sciences of the USA 108(2):458-462.

Durvasula, A., and Sankararaman, S. 2020. Recovering signals of ghost archaic introgression in African populations. Science Advances 6(7): eaax5097. doi: 10.1126/ sciadv.aax5097.

Fenderson, L.E., Kovach, A.I., and Llamas, B. 2020. Spatiotemporal landscape genetics: Investigating ecology and evolution through space and time. Molecular Ecology 29(2): 218-246.

Fregel, R., Mendez, F.L., Bokbot, Y., Martin-Socas, D., Camalich-Massieu, M.D., Santana, J., Morales, J., Avila-Arcos, M.C., Underhill, P.A., Shapiro, B., Wojcik, G., Rasmussen, M., Soares, A.E.R., Kapp, J., Sockell, A., Rodriguez-Santos, F.J., Mikdad, A., Trujillo-Mederos, A., and Bustamante, C.D. 2018. Ancient genomes from North Africa evidence prehistoric migrations to the Maghreb from both the Levant and Europe. Proceedings of the National Academy of Sciences of the USA 115(26): 6774-6779.

Gallego Llorente, M., Jones, E.R., Eriksson, A., Siska, V., Arthur, K.W., Arthur, J.W., Curtis, M.C., Stock, J.T., Coltorti, M., Pieruccini, P., Stretton, S., Brock, F., Higham, T., Park, Y., Hofreiter, M., Bradley, D.G., Bhak, J., Pinhasi, R., and Manica, A. 2015. Ancient Ethiopian genome reveals extensive Eurasian admixture throughout the African continent. Science 35o(6262): 820-822.

Greenberg, J.H. 1963. The languages of Africa. Indiana University Press: Bloomington, Indiana.

Gronau, I., Hubisz, M.J., Gulko, B., Danko, C.G., and Siepel, A. 2011. Bayesian inference of ancient human demography from individual genome sequences. Nature Genetics 43(10): 1031-1034.

Güldemann, T. 2018. The languages and linguistics of Africa. Walter de Gruyter GmbH \& Co KG.

Gunther, T., and Jakobsson, M. 2016. Genes mirror migrations and cultures in prehistoric Europe-a population genomic perspective. Current Opinion in Genetics and Development 41: 115-123. 
Henn, B.M., Botigue, L.R., Gravel, S., Wang, W., Brisbin, A., Byrnes, J.K., Fadhlaoui-Zid, K., Zalloua, P.A., Moreno-Estrada, A., Bertranpetit, J., Bustamante, C.D., and Comas, D. 2012. Genomic ancestry of North Africans supports back-to-Africa migrations. PLoS Genetics 8(1): e1002397.

Henn, B.M., Gignoux, C., Lin, A.A., Oefner, P.J., Shen, P., Scozzari, R., Cruciani, F., Tishkoff, S.A., Mountain, J.L., and Underhill, P.A. 2008. Y-chromosomal evidence of a pastoralist migration through Tanzania to southern Africa. Proceedings of the National Academy of Sciences of the USA 105(31): 10693-10698.

Henn, B.M., Steele, T.E., and Weaver, T.D. 2018. Clarifying distinct models of modern human origins in Africa. Current Opinion in Genetics and Development 53: 148-156.

Hollfelder, N., Schlebusch, C.M., Gunther, T., Babiker, H., Hassan, H.Y., and Jakobsson, M. 2017. Northeast African genomic variation shaped by the continuity of indigenous groups and Eurasian migrations. PLoS Genetics 13(8): e10o6976.

Hsieh, P., Woerner, A.E., Wall, J.D., Lachance, J., Tishkoff, S.A., Gutenkunst, R.N., and Hammer, M.F. 2016. Model-based analyses of whole-genome data reveal a complex evolutionary history involving archaic introgression in Central African Pygmies. Genome Research 26(3): 291-300.

Jobling, M.A., Hollox, E., Hurles, M., Kivisild, T., and Tyler-Smith, C. 2014. Human Evolutionary Genetics. 2nd ed. Taylor and Francis: New York, USA.

Lachance, J., Vernot, B., Elbers, C.C., Ferwerda, B., Froment, A., Bodo, J.M., Lema, G., Fu, W., Nyambo, T.B., Rebbeck, T.R., Zhang, K., Akey, J.M., and Tishkoff, S.A. 2012. Evolutionary history and adaptation from high-coverage whole-genome sequences of diverse african hunter-gatherers. Cell 15O(3): 457-469.

Li, S., Schlebusch, C., and Jakobsson, M. 2014. Genetic variation reveals large-scale population expansion and migration during the expansion of Bantu-speaking peoples. Proceedings of the Royal Society B: Biological Sciences 281(1793): 20141448.

Lipson, M., Ribot, I., Mallick, S., Rohland, N., Olalde, I., Adamski, N., Broomandkhoshbacht, N., Lawson, A.M., Lopez, S., Oppenheimer, J., Stewardson, K., Asombang, R.N., Bocherens, H., Bradman, N., Culleton, B.J., Cornelissen, E., Crevecoeur, I., de Maret, P., Fomine, F.L.M., Lavachery, P., Mindzie, C.M., Orban, R., Sawchuk, E., Semal, P., Thomas, M.G., Van Neer, W., Veeramah, K.R., Kennett, D.J., Patterson, N., Hellenthal, G., Lalueza-Fox, C., MacEachern, S., Prendergast, M.E., and Reich, D. 202O. Ancient West African foragers in the context of African population history. Nature 577(7792): 665-670. doi: 10.1038/s41586-020-1929-1.

Macholdt, E., Lede, V., Barbieri, C., Mpoloka, S.W., Chen, H., Slatkin, M., Pakendorf, B., and Stoneking, M. 2014. Tracing pastoralist migrations to southern Africa with lactase persistence alleles. Current Biology 24(8): 875-879.

Mitchell, P., and Lane, P. 2013. The Oxford handbook of African Archeology. Oxford University Press: Oxford, UK.

Nielsen, R., Akey, J.M., Jakobsson, M., Pritchard, J.K., Tishkoff, S., and Willerslev, E. 2017. Tracing the peopling of the world through genomics. Nature 541(7637): 302-310. 
Novembre, J., Johnson, T., Bryc, K., Kutalik, Z., Boyko, A.R., Auton, A., Indap, A., King, K.S., Bergmann, S., Nelson, M.R., Stephens, M., and Bustamante, C.D. 2008. Genes mirror geography within Europe. Nature 456(7218): 98-101.

Pickrell, J.K., Patterson, N., Barbieri, C., Berthold, F., Gerlach, L., Guldemann, T., Kure, B., Mpoloka, S.W., Nakagawa, H., Naumann, C., Lipson, M., Loh, P.R., Lachance, J., Mountain, J., Bustamante, C.D., Berger, B., Tishkoff, S.A., Henn, B.M., Stoneking, M., Reich, D., and Pakendorf, B. 2012. The genetic prehistory of southern Africa. Nature Communications 3: 1143 .

Pickrell, J.K., Patterson, N., Loh, P.R., Lipson, M., Berger, B., Stoneking, M., Pakendorf, B., and Reich, D. 2014. Ancient west Eurasian ancestry in southern and eastern Africa. Proceedings of the National Academy of Sciences of the USA 111(7): 2632-2637.

Prendergast, M.E., Lipson, M., Sawchuk, E.A., Olalde, I., Ogola, C.A., Rohland, N., Sirak, K.A., Adamski, N., Bernardos, R., Broomandkhoshbacht, N., Callan, K., Culleton, B.J., Eccles, L., Harper, T.K., Lawson, A.M., Mah, M., Oppenheimer, J., Stewardson, K., Zalzala, F., Ambrose, S.H., Ayodo, G., Gates, H.L., Jr., Gidna, A.O., Katongo, M., Kwekason, A., Mabulla, A.Z.P., Mudenda, G.S., Ndiema, E.K., Nelson, C., Robertshaw, P., Kennett, D.J., Manthi, F.K., and Reich, D. 2019. Ancient DNA reveals a multistep spread of the first herders into sub-Saharan Africa. Science 365(6448): eaaw6275.

Rodriguez-Varela, R., Gunther, T., Krzewinska, M., Stora, J., Gillingwater, T.H., MacCallum, M., Arsuaga, J.L., Dobney, K., Valdiosera, C., Jakobsson, M., Gotherstrom, A., and Girdland-Flink, L. 2017. Genomic analyses of pre-European conquest human remains from the Canary islands reveal close affinity to modern North Africans. Current Biology 27(21): 3396-3402 e3395.

Scerri, E.M.L., Thomas, M.G., Manica, A., Gunz, P., Stock, J.T., Stringer, C., Grove, M., Groucutt, H.S., Timmermann, A., Rightmire, G.P., d'Errico, F., Tryon, C.A., Drake, N.A., Brooks, A.S., Dennell, R.W., Durbin, R., Henn, B.M., Lee-Thorp, J., deMenocal, P., Petraglia, M.D., Thompson, J.C., Scally, A., and Chikhi, L. 2018. Did Our Species Evolve in Subdivided Populations across Africa, and Why Does It Matter? Trends in Ecology and Evolution 33(8): 582-594.

Scheinfeldt, L.B., Soi, S., Lambert, C., Ko, W.Y., Coulibaly, A., Ranciaro, A., Thompson, S., Hirbo, J., Beggs, W., Ibrahim, M., Nyambo, T., Omar, S., Woldemeskel, D., Belay, G., Froment, A., Kim, J., and Tishkoff, S.A. 2019. Genomic evidence for shared common ancestry of East African hunting-gathering populations and insights into local adaptation. Proceedings of the National Academy of Sciences of the USA 116(10): 4166-4175.

Schlebusch, C.M. 2019. Population migration and adaptation during the African Holocene: A genetic perspective. In: Modern Human Origins and Dispersal, edited by Y. Sahle, H. Reyes-Centeno and C. Bentz. Kerns Verlag: Tuebingen, Germany. 
Schlebusch, C.M., and Jakobsson, M. 2018. Tales of Human Migration, Admixture, and Selection in Africa. Annual Review of Genomics and Human Genetics 19: 405-428.

Schlebusch, C.M., Malmstrom, H., Gunther, T., Sjodin, P., Coutinho, A., Edlund, H., Munters, A.R., Vicente, M., Steyn, M., Soodyall, H., Lombard, M., and Jakobsson, M. 2017. Southern African ancient genomes estimate modern human divergence to 350,0oo to 260,ooo years ago. Science 358(6363): 652-655.

Schlebusch, C.M., Skoglund, P., Sjodin, P., Gattepaille, L.M., Hernandez, D., Jay, F., Li, S., De Jongh, M., Singleton, A., Blum, M.G., Soodyall, H., and Jakobsson, M. 2012. Genomic Variation in Seven Khoe-San Groups Reveals Adaptation and Complex African History. Science 338(6105): 374-379.

Schuenemann, V.J., Peltzer, A., Welte, B., van Pelt, W.P., Molak, M., Wang, C.C., Furtwangler, A., Urban, C., Reiter, E., Nieselt, K., Tessmann, B., Francken, M., Harvati, K., Haak, W., Schiffels, S., and Krause, J. 2017. Ancient Egyptian mummy genomes suggest an increase of Sub-Saharan African ancestry in post-Roman periods. Nature Communications 8: 15694 .

Semo, A., Gaya-Vidal, M., Fortes-Lima, C., Alard, B., Oliveira, S., Almeida, J., Prista, A., Damasceno, A., Fehn, A.M., Schlebusch, C., and Rocha, J. 2019. Along the Indian Ocean coast: genomic variation in Mozambique provides new insights into the Bantu expansion. Molecular Biology and Evolution 37(2): 406-416.

Skoglund, P., Thompson, J.C., Prendergast, M.E., Mittnik, A., Sirak, K., Hajdinjak, M., Salie, T., Rohland, N., Mallick, S., Peltzer, A., Heinze, A., Olalde, I., Ferry, M., Harney, E., Michel, M., Stewardson, K., Cerezo-Roman, J.I., Chiumia, C., Crowther, A., Gomani-Chindebvu, E., Gidna, A.O., Grillo, K.M., Helenius, I.T., Hellenthal, G., Helm, R., Horton, M., Lopez, S., Mabulla, A.Z.P., Parkington, J., Shipton, C., Thomas, M.G., Tibesasa, R., Welling, M., Hayes, V.M., Kennett, D.J., Ramesar, R., Meyer, M., Paabo, S., Patterson, N., Morris, A.G., Boivin, N., Pinhasi, R., Krause, J., and Reich, D. 2017. Reconstructing Prehistoric African Population Structure. Cell 171(1): 59-71 e21.

Stringer, C. 2002. Modern human origins: progress and prospects. Philosophical Transactions of the Royal Society of London B: Biological Sciences 357(1420): 563-579.

Stringer, C. 2016. The origin and evolution of Homo sapiens. Philosophical Transactions of the Royal Society of London B: Biological Sciences 371(1698).

Tishkoff, S.A., Reed, F.A., Friedlaender, F.R., Ehret, C., Ranciaro, A., Froment, A., Hirbo, J.B., Awomoyi, A.A., Bodo, J.M., Doumbo, O., Ibrahim, M., Juma, A.T., Kotze, M.J., Lema, G., Moore, J.H., Mortensen, H., Nyambo, T.B., Omar, S.A., Powell, K., Pretorius, G.S., Smith, M.W., Thera, M.A., Wambebe, C., Weber, J.L., and Williams, S.M. 2009. The genetic structure and history of Africans and African Americans. Science 324(5930): 1035-1044. 
Vai, S., Sarno, S., Lari, M., Luiselli, D., Manzi, G., Gallinaro, M., Mataich, S., Hubner, A., Modi, A., Pilli, E., Tafuri, M.A., Caramelli, D., and di Lernia, S. 2018. Ancestral mitochondrial N lineage from the Neolithic 'green' Sahara. Scientific Reports 9(1): 3530. van de Loosdrecht, M., Bouzouggar, A., Humphrey, L., Posth, C., Barton, N., Aximu-Petri, A., Nickel, B., Nagel, S., Talbi, E.H., El Hajraoui, M.A., Amzazi, S., Hublin, J.J., Paabo, S., Schiffels, S., Meyer, M., Haak, W., Jeong, C., and Krause, J. 2018. Pleistocene North African genomes link Near Eastern and sub-Saharan African human populations. Science $360(6388)$ : 548-552.

Veeramah, K.R., Wegmann, D., Woerner, A., Mendez, F.L., Watkins, J.C., Destro-Bisol, G., Soodyall, H., Louie, L., and Hammer, M.F. 2011. An early divergence of KhoeSan ancestors from those of other modern humans is supported by an ABC-based analysis of autosomal resequencing data. Molecular Biology and Evolution 29(2): 617-63o.

Vicente, M., Jakobsson, M., Ebbesen, P., and Schlebusch, C.M. 2019. Genetic Affinities among Southern Africa Hunter-Gatherers and the Impact of Admixing Farmer and Herder Populations. Molecular Biology and Evolution 36(9): 1849-1861 